\begin{tabular}{c} 
Volume and Issues Obtainable at Center for Sustainability Research and Consultancy \\
Journal of Business and Social Review in Emerging Economies \\
ISSN: 2519-089X (E): 2519-0326 \\
Volume 7: No. 1, March 2021 \\
CSRᄃ \\
Journal homepage: www.publishing.globalcsrc.org/jbsee \\
\hline
\end{tabular}

\title{
The Socio-Economic Effect of Remittances on Left behind Families in District Chitral
}

Anwarul Mujahid Shah, Department of Sociology, Political Science and Education, Bacha Khan University, Charsadda, Pakistan

*Muhammad Kamran Khan, Department of Management Sciences \& Commerce, Bacha Khan

University, Charsadda, Pakistan

Nauman Reayat, Department of Political Science, Abdul Wali Khan University, Mardan, Pakistan

*Corresponding author's email address: drkamrankhan@bkuc.edu.pk

\begin{tabular}{ll}
\hline \multicolumn{1}{c}{ ARTICLE DETAILS } & ABSTRACT \\
\hline $\begin{array}{l}\text { History } \\
\text { Revised format: Feb 2021 }\end{array}$ & $\begin{array}{l}\text { The study was initiated to measure the utilization of remittances on } \\
\text { productive and nonproductive purposes in the hilly area of district }\end{array}$ \\
Available Online: Mar 2021 & Chitral. Three villages were purposively selected for analysis, and \\
\hline Keywords & 150 respondents were selected randomly for face-to-face interview. \\
Remittances, Income, & The utilization was measured using t-test and percentage changes. \\
Education, Migrants, & The main indicators used in the research were education, income and \\
Expenditure. & expenditure. It was found that the remittances have a positive impact \\
JEL Classification: & $\begin{array}{l}\text { on the families left behind by the migrants. Thus overall, the results } \\
\text { showed a positive effect on the socio-economic wellbeing of the } \\
\text { M0, M1 }\end{array}$ \\
& respondents.
\end{tabular}

Recommended citation: Shah, A. M., Khan, M. K. \& Reayat, N. (2021). The Socio-Economic Effect of Remittances on Left behind Families in District Chitral. Journal of Business and Social Review in Emerging Economies, 7(1), 195-200.

\section{Introduction}

The labor emigration started immediately after independence in 1947 in Pakistan when the flow to foreign countries continued at a steady pace that begins in Middle Eastern countries in the wake of the rise in the oil price (Shehnaz, 1986). The migration to a broad from Pakistan happens for the last many year and wages abroad are remarkably high as compared to wages in Pakistan. The migrants remitted the money in a lump sum to their home. On the other side, they bring the money with them on coming home. Moreover, they also bring valuable good to them. Foreign remittances are the main source of foreign exchange in Pakistan. The remittances increased from 3.9 billion dollars in 20032004 to 8.50 billion dollars in 2010-2011 (World Bank, 2012). In Khyber Pakhtunkhwa (KP), most of the workers going abroad hail from rural areas; likewise, most of the money coming to the Province goes there (Khan, 1990). No census has been conducted of the Pakistanis living in the Middle East. However, various estimates on the subject suggest that their number would be between 1.5-2.0 million. Although return flow has started on a noticeable scale, yet the present number of Pakistanis, there must be well over one million, which is by all standards a large number (Hussian, 2006). Information on the exact number of people of KP origin in the Middle East is not available. But it is believed to be in the high thousands. Even by a more conservative estimate, based on information collected by the Manpower 
Division, Pakistan; it would be around 150,000 min which is more than the number of workers employed in the registered industrial units of KP in 1985 (Rabi2001). According to the 1988 census of settlement, the total number of persons migrated from these settlements were 14504 from the Chitral. Out of which $96 \%$ were male, and $4 \%$ were females (Hussain, 2006). There are large numbers of benefits from the remittances from the recipients' countries. Income distribution and socio-economic conditions can be improved. It is more useful when poor and unskilled labour goes abroad. The results of the research activities showed that remittances had been used for domestic consumption, health, education and for the better standard of living as compared to the non-migrants household. (Clark and Thompson, 1990). The social status of people also improved after migration, their income level, the outlook of their houses, occupations, education level of children, the health status of family members improved in a positive direction. Overall facilities like schools, colleges, shopping centres, road transportation, electrification, communications and banking facilities improved and developed. Spending on nonproductive activities like marriages, ceremonies, gifts to friends/ relatives, spending on festivals and funerals has also risen due to remittances. But along with these positive impacts; there are certain factors such as negligence of child care, the excessive workload on woman, frustration of the left-behind families, psychological disorder and delinquency. So, the migrant remittances had a profound socioeconomic impact on the left behind family members as well in the country. A study of these changes can prove helpful in analyzing and understanding the process of social and economic transformation, and to furnish guidelines for the policies in the relevant fields. The Chitral valley is among one of those regions of the country, which possesses both natural beauty and natural resources; but the majority of people residing in rural areas is still facing problems and devoid of amenities of life. More than 80 percent of the households have less than 2 hectares. (Main, 1986). Farmers with small holdings, land fragmentation not only failed to practice proper rotation of crops but also not able to carry on stock rising. So, the poor economic condition, unemployment and low income compel dwellers for overseas migrations. The growing trend of migrants abroad and corresponding inflow of remittances has brought the socio-economic impact on the left-behind families. In order to understand implications, for future planning, the impact study of remittances is essential.

\section{Objectives of the Study}

To examine the effect of remittances on the socio-economic conditions in the study area.

\section{Literature Review}

Review of the relevant literature is vital to get some help for the conceptual framework for this study. The findings of various studies conducted in the past are briefly presented.

Mehta (1991) conducted a study in three villages in Uttar Pradesh. He interviewed 205 migrant households. An attempt was made to highlight the characteristics of migration and its effects on patterns of the income distribution. He had been found that migration has positively affected the socio-economic conditions of the households, transportation and communication development, level of education, and physical conditions of the area. He reported that the household income rose significantly after migration reduced the income inequalities.

Minhas (1992) conducted a survey in three villages of Faisalabad district in Pakistan. He interviewed rural youth and asked about the causes of migration from 148 men and 102 women. The majority of rural youth were not satisfied with their rural community life due to scarcity of basic life necessities, and they see migration as a mean of social and economic betterment.

Saif (2000) discussed the investment patterns of overseas remittances in hilly areas of Northern Punjab, Pakistan. Data was collected from Union Council Derya Gali. In this study migrants, returned migrant and non-migrants were examined. It was found that household consumption has improved and marriage was their priority for the spending of remittance while education and commercial activities received less attention. 
Rabbi (2001) studied overseas emigration and its impact on local communities. The study was conducted in three selected villages of District Swat. He concluded that younger people tended more to migrate, and the Middle East is the most favoured destination of emigrants followed by the USA. Major causes of migration are poor economic conditions and unemployment. Overseas emigration had a significant effect on the economic well being of the people in the study area. Their monthly income has substantially increased after emigration, and their households also start saving, purchased new landholdings, construct new houses and investment in the existing business. Edwards and Ureta (2003) conducted a research study in El Salvador, and he found that the effect of remittances was high on health and education. They found that remittances not only improved physical investment but also enhanced health and education. In recipients' families, the enrollment in school increased, and dropout rate minimized. Chami, et al., (2003) reported that remittances provide benefits to the return migrants as well as the recipient households. The increased income provides security on time of external shocks. Remittances that are part of productive investment tend to have an impact on long-term poverty reduction, resulting in less vulnerability both at the household and community level. There may also be a reduction in inter-household inequality. When remittances are used in local consumption, this can have a short-term significance only and can also increase inter-household inequality.

Koc and Onan (2004) found the positive effect of remittance on the income of recipient households. But they mentioned that large portion of remittances go to non-productive investment, i.e. houses consumer durables. Adams (2005) conducted the study and found that remittances have played an important role in reducing poverty in Uganda, Bangladesh, Ghana and Guatemala. The recipient's expenditure on health, consumer durables, education has increased significantly. Cordova (2006) provided evidence that in Mexico due to remittances school attendance increased, infant mortality reduced, and child illiteracy decreased. Gunasekera (2006) revealed that overseas workers of Sri Lanka had contributed significantly to the reduction in unemployment and poverty, especially in rural areas of the country. Migrants could contribute to the growth of recipient countries. Haasa (2006) discussed that impact of migration had brought tremendous benefits. He used the research of several authors and reached to the conclusion that the migrant's families have a higher propensity to investment as compared to non-migrants. The spending in houses, small businesses and education proved positive income multiplier effects in the recipient's families. He maintained remittances have contributed significantly to the welfare of people, economic development, and investment in houses, agriculture and enterprises, enhanced the education of younger households. Yang (2006) discussed the effects of inflow of remittances on households. He found that remittances and agriculture are two main components for diminishing poverty in Nepal since 1996. Migration facilities households in a financial emergency like mortality, medical expenditures, or loss of work in the family. The remittances accepting families prefer the education of children and household amenities. Canales (2007) reported that the returned migrants living position had enhanced considerably. Remittances improved the economic base of the households. Economic inequality reduced at the regional and local level.

Yang (2008) recorded that research in migration economics has described numerous beneficial influences of remittances on the welfare and investments by the recipient households. He noted that the flow of remittances has increased the income of migrant families substantially in the Philippines and they are more expected to leave poverty status, send their children to school, and invest in new entrepreneurial enterprises.

Drinkwater et al., (2009) analyzed that remittances possess a low damning effect on unemployment but a positive and significant effect on investment. The negative effect was dependency habits among the recipient families. Lokshin (2009) mentioned that increased inflow of remittances had improved socioeconomic, demographic and political condition in Nepal. In Nepal between 1995 and 2004, the poverty rate declined 20 percent. 
Niaz et al., (2010) examined the role of remittances of overseeing emigrants in strengthening the ability of their left-behind families to protect against socio-economic discomforts of life. One hundred emigrant families were accessed for interviews through snowball sampling method in four villages of Lower Dir district in the year 2008. The major findings of the study showed that remittances had improved the social status of emigrant families by improving their lifestyle, furnishing them with the opportunity to send children to standard educational institutions, and changing the behaviour of relatives/ friends towards the recipient families. The recipient families generated different forms of economic activities such as micro-level business, invest in real estate, and purchase of agricultural land etc. The study recommends that the government and other concerned departments should provide a secure and conducive environment for emigrant families to utilize remittances at a national level. Khan et al., (2011) analyzed the impact of remittances on the socio-economic conditions of rural families of district Poonch of Azad Jammu and Kashmir in 2008. The findings of the study revealed that the main source of income in the area was remittances. Before emigration the incomes of people were very low, which significantly improved after emigration, savings of people become many-fold higher, expenditure on their basic needs, ceremonies and luxury items significantly increased. After an increase in incomes, the emigrants preferred to send their children to private educational institutions. Moreover, families spent income for the purchase of commercial plots, repaid their debts, constructed and renewed their houses, purchased more vehicles and started new businesses in the area. The study recommends that for better utilization of the remittances, proper training is required on the leftover family members so that the investment may be made in such a way to generate employment in the area.

\section{Methodology \\ Data Collection}

The data were collected through questionnaire from 150 households of migrants residing in Khot, Rech and Ujnu respectively. Primary data were collected through face-to-face interviews. A comprehensive interview schedule was designed in light of the objectives of the study. The collected data were analyzed through statistical packages for social sciences (SPSS). Some of the socio-economic characteristics were explained by descriptive statistics. i-e simple data analysis was performed, including percentages change and frequency distributions paired t-test was used as a statistical model to identify the significant difference before and after migration.

\section{Results and Discussion Effect on Income}

Table 1 shows the income effect of remittances on the migrants. The percentage change for the study area was $102.29 \%$. The paired test was significant at the $1 \%$ level. This accepts the alternative hypothesis that remittances have a significant effect on the increase of income of migrants. Village wise data shows that the biggest \% change was observed in the village Khot followed by village Ujnu. The percentage change was 106.52 and 100.16 percent for Khot and Ujnu, respectively. The percentage change was a little bit low for village Rech. The possible explanation for this may be that a majority of these villages maybe are labourers as compared to other two villages.

Table 1: Mean Difference and t-test for income

\begin{tabular}{|l|c|c|c|c|}
\hline Villages & Khot & Rech & Ujnu & All \\
\hline Before & $\mathbf{1 5 7 9 7 0 . 1}$ & $\mathbf{1 6 8 3 4 2 . 9}$ & $\mathbf{1 6 2 5 2 1 . 7}$ & $\mathbf{1 6 2 3 6 0}$ \\
\hline After & $\mathbf{3 2 6 2 3 8 . 8}$ & $\mathbf{3 3 5 6 5 7 . 1}$ & $\mathbf{3 2 5 3 0 4 . 3}$ & $\mathbf{3 2 8 4 4 0}$ \\
\hline \% Change & $\mathbf{1 0 6 . 5 2}$ & $\mathbf{9 9 . 3 9}$ & $\mathbf{1 0 0 . 1 6}$ & $\mathbf{1 0 2 . 2 9}$ \\
\hline T-test & - & - & - & $\mathbf{6 9 . 6}$ \\
\hline P values & - & - & - & $\mathbf{0 . 0 0 0}$ \\
\hline
\end{tabular}

*significant at $1 \%$ level 


\section{Effect on Expenditure}

Table no. 2 shows the position of expenditure of sample migrants. The percentage was 48.53 for the study area. The t-test was 6.08 , rejecting the HO that remittances have no significant effects on their families. The percentage \% for village Khot was 59.97\%. The change for village Rech and Ujnu was $39.59 \%$ and $26.78 \%$ respectively. The percentage change was less as compared to percentage change in income. The reason seems to be logical that income has increased more proportionately as compared to expenditure. The migrants prefer to save more money for the investment in moveable and immovable assets.

Table 2: Mean Difference and t-test for Expenditure.

\begin{tabular}{|l|c|c|c|c|}
\hline Villages & Khot & Rech & Ujnu & All \\
\hline Before & $\mathbf{1 6 6 4 2 7 . 9}$ & $\mathbf{1 6 0 8 5 7 . 1}$ & $\mathbf{1 6 2 2 8 2 . 6}$ & $\mathbf{1 6 2 2 6 6 . 7}$ \\
\hline After & $\mathbf{2 6 5 7 3 4 . 7}$ & $\mathbf{2 2 4 5 4 5 . 3}$ & $\mathbf{2 0 5 7 4 4 . 6}$ & $\mathbf{2 4 1 0 2 2 . 1}$ \\
\hline \% Change & $\mathbf{5 9 . 6 7}$ & $\mathbf{3 9 . 5 9}$ & $\mathbf{2 6 . 7 8}$ & $\mathbf{4 8 . 5 3}$ \\
& & & & \\
\hline T-test & - & - & - & $\mathbf{6 . 0 8} *$ \\
\hline P values & - & - & - & $\mathbf{0 . 0 0 0}$ \\
\hline
\end{tabular}

*significant at $1 \%$ level

\section{Educational Status of the Sample Emigrant's Children}

Table 3 shows the education enrollment of the emigrants. The enrollments have increased from Government schools to private schools. In the study area, the enrollment in Government schools decreased from 127 to 62 , showing $-51.18 \%$ changes. Village wise data show that the greatest change was observed in Rech, followed by Ujnu. As compare to villages the change was lowest in village Khot. This shows that due to remittances, people prefer to send their children to private-run schools and easily can afford the expenses of private schools.

Table 3: Educational Status of the Sample Emigrant's Children

\begin{tabular}{|c|c|c|c|c|c|c|}
\hline \multirow{2}{*}{$\begin{array}{l}\text { Education } \\
\text { status }\end{array}$} & \multicolumn{2}{|c|}{ Public school } & \multirow{2}{*}{$\begin{array}{c}\% \text { age } \\
\text { change }\end{array}$} & \multicolumn{2}{|c|}{ Private School } & \multirow{2}{*}{$\begin{array}{c}\text { \%age } \\
\text { Change }\end{array}$} \\
\hline & BM & $\mathbf{A M}$ & & $\mathbf{B M}$ & $\mathbf{A M}$ & \\
\hline Khot & 56 & 32 & -42.87 & 11 & 35 & 218.1 \\
\hline Rech & 41 & 18 & -56.09 & 06 & 29 & 383.3 \\
\hline Ujnu & 30 & 12 & -60 & 06 & 24 & 300 \\
\hline All & 127 & 62 & -51.18 & 23 & 88 & 282.7 \\
\hline
\end{tabular}

\section{Recommendations and Conclusion}

Oversees migration had a significant effect on the economic wellbeing of the people in the study area. The monthly income has substantially increased, and the expenditure on food items and other family requirements have also enhanced. This proofs that the standard of living has improved in the study area. In education, the migrants were able to provide better education for their children. Overall the impact of remittances on the socio-economic wellbeing of migrants was positive. In order to increase local employment and improve the earning of migrants, the remittances should be used for productive purposes by immigrant families. To meet the financial emergencies, saving habits should be encouraged through community organization established in villages by different non-Government organizations likewise the government through small and medium enterprises development agency should help and guide migrant families to start small business activities and in order to get reasonable income and compete with other nations, the government should provide technical training and short duration workshops.

\section{References}

Adams Jr, R. H., \& Page, J. (2005). Do international migration and remittances reduce poverty in developing countries?. World Development, 33(10), 1645-1669. 
Canales, A. I. (2007). Remittances, development and poverty in Mexico: A critical view. New perspectives on remittances from Mexicans and Central Americans in the United States, 4, 59-101.

Chami, R., Fullenkamp, C., \& Jahjah, S. (2005). Are immigrant remittance flows a source of capital for development?. IMF Staff Papers, 52(1), 55-81.

Clark, D. P., \& Thompson, H. (1990). Factor migration and income distribution in some developing countries. Bulletin of Economic Research, 42(2), 131-140.

Córdova, J. E. L. (2006). Globalization, migration and development: the role of Mexican migrant remittances (Working Paper ITD= Documento de Trabajo ITD; $n$. 20) (Vol. 20). BID-INTAL.

Drinkwater, S., Eade, J., \& Garapich, M. (2009). Poles apart? EU enlargement and the labour market outcomes of immigrants in the United Kingdom. International Migration, 47(1), 161-190.

Edwards, A. C., \& Ureta, M. (2003). International migration, remittances, and schooling: evidence from El Salvador. Journal of development economics, 72(2), 429-461.

Fazli, Rabbi. (2001). A Study of Overseas Emigration and its Socio-Economic Impact on the Local Community to Distt. Swat. (A case study of three selected villages). An unpublished thesis, institute of Development Studies. N.W.F.P Agricultural University Peshawar.

Gunasekera, H. R. (2006, December). Development of international migration statistics in Sri Lanka. In UN Expert Group Meeting on "Measuring international migration: Concepts and methods (pp. 4-7).

De Haas, H. (2006). Migration, remittances and regional development in Southern Morocco. Geoforum, 37(4), 565-580.

Husain .Z, (2006.) Effect of remittances on the Socio-Economic condition of rural household on district Chitral. Institute of Development Studies, NWFP Agricultural University Peshawar.

Khan, H., Israr, M., Summar, M., Shaukat, S. N., Khan, M., Ahmad, N., \& Karim, R. (2011). Impact of remittances on the socio-economic conditions of rural families in district Poonch of Azad Jammu and Kashmir. Sarhad Journal of Agriculture, 27(4), 625-632.

Koc, I., \& Onan, I. (2004). International migrants' remittances and welfare status of the left-behind families in Turkey. International Migration Review, 38(1), 78-112.

Mehta, G.S. (1991). Characteristics and Economic Implications of Migration. Journal of Rural Development Hyderabad 10 (6) : 731-744.

Mian.N(1986) Malakand area development project :Agro-socio Economics study of Chitral district publication 192 Institute of development study(IDS) Agricultural University Peshawar.

Minhas, I.A. (1992). Socio-Economic, Physical and Psychological Factors in Migration Plans of Rural Youth. (A study investigating sex differential). Journal of Rural Development and Administration. 24 (3): 119-136.

Mwakaje A.G(2013). The impact of climate change and variability on agro-pastoralists' economy in Tanzania. Journal of Environmental Economics 4(1):30-38

Muhammad, N., Ahmad, N., Shah, M., Alam, I., \& Jawad, M. (2010). The impact of foreign remittances on the socio-economic conditions of households. Sarhad, Journal of Agriculture, 26(1), 141-145.

Saif-ur-Rehman. (2000) Investment Pattern of Remittances Income in the Families Left Behind. Pakistan Agricultural Research Council (PARC), Islamabad, Pakistan. Sarhad Journal of Agriculture 16:5, 545-552.

Shehnaz. (1986). Impact of Male Emigration on the Role of Rural Women in Kohat District. Institute of development studies .NWFP Agricultural University Peshawar.

World Bank (2012). Development Prospects Migration Policy Institute. Washington D.C

Yang, D. (2006). Why Do Migrants Return to Poor Countries? Evidence from Philippine Migrants' Exchange Rate Shocks, Review of Economics and Statistics 88:4, 715- 735.

Yang, D. (2008). International Migration, Remittances, and Household Investment: Evidence from Philippine Migrants' Exchange Rate Shocks, Economic Journal 118: 591-630. 